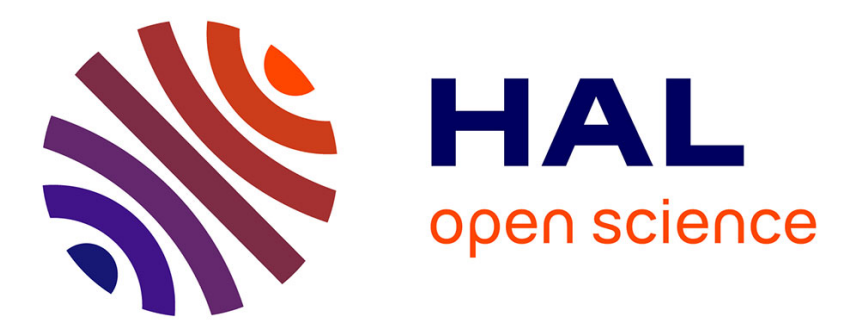

\title{
UCP1 transrepression in Brown Fat in vivo and mineralocorticoid receptor anti-thermogenic effects
}

Emmanuelle Kuhn, Khadija Lamribet, Say Viengchareun, Damien Le Menuet, Bruno Fève, Marc Lombès

\section{- To cite this version:}

Emmanuelle Kuhn, Khadija Lamribet, Say Viengchareun, Damien Le Menuet, Bruno Fève, et al.. UCP1 transrepression in Brown Fat in vivo and mineralocorticoid receptor anti-thermogenic effects. Annales d'Endocrinologie, 2019, 80 (1), pp.1-9. 10.1016/j.ando.2018.04.018 . hal-02189371

\section{HAL Id: hal-02189371 \\ https://hal.sorbonne-universite.fr/hal-02189371}

Submitted on 19 Jul 2019

HAL is a multi-disciplinary open access archive for the deposit and dissemination of scientific research documents, whether they are published or not. The documents may come from teaching and research institutions in France or abroad, or from public or private research centers.
L'archive ouverte pluridisciplinaire HAL, est destinée au dépôt et à la diffusion de documents scientifiques de niveau recherche, publiés ou non, émanant des établissements d'enseignement et de recherche français ou étrangers, des laboratoires publics ou privés. 


\title{
UCP1 transrepression in Brown Fat in vivo and mineralocorticoid receptor anti-thermogenic effects
}

\author{
L'effet anti-thermogénique du récepteur minéralocorticoüde in vivo et in vitro par inhibition de \\ l'expression d'UCP1
}

\author{
Emmanuelle Kuhn ${ }^{\mathrm{a}, \mathrm{b}}$, Khadija Lamribet ${ }^{\mathrm{a}}$, Say Viengchareun ${ }^{\mathrm{a}}$, Damien Le Menuet $^{\mathrm{a}}$, \\ Bruno Fève ${ }^{\mathrm{c}, \mathrm{d}, \mathrm{e}}$, Marc Lombès ${ }^{\mathrm{a}, \mathrm{b}, *}$ \\ ${ }^{a}$ Inserm U1185, Faculté de Médecine Paris-Sud, Université Paris-Sud, Université Paris-Saclay, 94276 Le Kremlin-Bicêtre, France \\ ${ }^{\mathrm{b}}$ Service d'endocrinologie et des maladies de la reproduction, Hôpital de Bicêtre, Assistance Publique-Hôpitaux de Paris, 94275 Le Kremlin-Bicêtre, France \\ ${ }^{\mathrm{c}}$ Inserm UMR_S938, Centre de recherche Saint-Antoine, Sorbonne Université, 75012 Paris, France \\ ${ }^{\mathrm{d}}$ Institut Hospitalo-Universitaire ICAN, Paris, France \\ e Service d'endocrinologie, Hôpital Saint-Antoine, Assistance publique-Hôpitaux de Paris, 75012 Paris, France
}

\begin{abstract}
Objectives. - The mineralocorticoid receptor (MR), a hormone-activated transcription factor, besides its role in controlling hydroelectrolytic homeostasis, exerts pro-adipogenic and anti-thermogenic effects, inhibiting mitochondrial-uncoupling protein UCP1 expression in brown adipocytes. The aim of this study was to gain insight into the molecular mechanisms by which MR participates in such metabolic regulation. Methods. We evaluated in vivo MR effects on cold-induced UCP1 expression in MR-overexpressing mice. Expression profiles of several transcriptional coregulators were analyzed during differentiation of the brown adipocyte T37i cell line. Given that UCP1 expression is inversely controlled by catecholamines/retinoic acid and corticosteroids, we investigated the mechanisms of MR's inhibitory effect on UCP1 transcription in T37i cells. Chromatin immunoprecipitation (ChIP) experiments enabled us to explore MR interaction with UCP1 promoter regions. Results. - Cold-induced UCP1 expression was blunted in the brown fat of MR-overexpressing mice. Along with induction of increasing mRNA levels for specific adipocyte markers during T37i differentiation, MR coactivator transcript levels significantly increased in intermediate states of differentiation, whereas expression of MR corepressors transiently increased approximately 2-fold. Such a simultaneous transient peak in coregulator expression is consistent with physiologically relevant cooperation occurring during brown adipogenesis. ChIP demonstrated that, after retinoic acid stimulation and aldosterone exposure, MR and PPAR $\gamma$ concomitantly bind to specific UCP1 promoter motifs. Conclusion. - Our studies demonstrate that MR exerts a pivotal metabolic role by controlling energy expenditure, and provide novel information on how MR participates in the regulation of brown adipocyte function.
\end{abstract}

Keywords: Brown adipose tissue; Mineralocorticoid receptor; Coregulators; Uncoupling protein 1; Thermogenesis

Résumé

Objectifs. - Le but de cette étude était de mieux comprendre les mécanismes moléculaires sous-tendant les effets métaboliques du récepteur minéralocorticoïde (MR), un facteur de transcription qui exerce un rôle pro-adipogénique et anti-thermogénique en inhibant l'expression de la protéine découplante mitochondriale de type 1 UCP1. Méthodes. - L'expression d'UCP1, induite par le froid, a été étudiée dans un modèle de souris transgéniques surexprimant le MR. Nous avons également déterminé le profil d'expression de certains corégulateurs au cours de l'adipogenèse en utilisant les cellules T37i, une lignée murine préadipocytaire brune. La précipitation de la chromatine (ChiP) a permis d'évaluer la capacité du MR à interagir avec certaines séquences régulatrices du promoteur d'UCP1. Résultats. - Nous montrons que la surexpression du MR in vivo inhibe l'expression d'UCP1 induite par le froid dans le tissu adipeux brun. Le profil d'expression de certains coactivateurs/corégulateurs du MR diffère clairement en fonction du caractère transitoire ou soutenu de leur niveau d'expression au cours de l'adipogenèse brune, témoignant d'une

\footnotetext{
* Corresponding author. Inserm U1185, Faculté de Médecine Paris-Sud, 63, rue Gabriel-Péri, 94276 Le Kremlin-Bicêtre, France.

E-mail address: marc.lombes@u-psud.fr (M. Lombès).
} 
coopération fonctionnelle en rapport avec la maturation adipocytaire. L'activation du MR inhibe l'expression d'UCP1 induite par les catécholamines et l'acide rétinoïque. La ChiP a démontré l'interaction du MR et de PPAR $\gamma$ sur le promoteur d'UCP1, identifiant le mécanisme d'inhibition de l'expression d'UCP1 par le MR activé par l'aldostérone.

Conclusion. - L'ensemble de ces résultats montre que le MR joue un rôle métabolique central en contrôlant la fonction adipocytaire brune et la dépense énergétique.

Mots clés : Tissu adipeux brun ; Récepteur minéralocorticoïde ; Corégulateurs ; Protéine découplante de type 1 UCP1 ; Thermogenèse

\section{Introduction}

Increasing energy expenditure could represent an interesting strategy to treat or prevent metabolic diseases, stimulating interest on brown adipose tissue (BAT) physiology [1,2]. The main role of BAT is non-shivering thermogenesis via uncoupling protein 1 (UCP1) [3]. UCP1 expression is under the control of several signaling pathways including insulin, retinoic acid (RA) derivatives, catecholamines, and of specific transcription factors such as retinoic acid receptor (RXR), PPAR $\gamma$ (peroxisome proliferator-activated receptor- $\gamma$ ), and the coactivator PGC-1 $\alpha$ (PPAR- $\gamma$ coactivator- $1 \alpha$ ), which is strongly induced by cold exposure or $\beta$-adrenergic stimulation [4]. BAT re-emerges as an important metabolic player in humans regulating energy homeostasis and thermogenesis. Numerous studies have shown that changes in BAT activity could profoundly affect body composition, energy and glucose homeostasis [5-9] and lipid metabolism $[10,11]$. Understanding how regulatory factors control brown adipocyte commitment and function is thus a critical challenge. We demonstrated that the mineralocorticoid receptor (MR), a steroid receptor belonging to the nuclear receptor superfamily of transcription factors, besides its role in electrolyte and water homeostasis, acts as a pro-adipogenic and anti-thermogenic factor that inhibits mitochondrial UCP1 expression $[12,13]$. Transgenic mouse model expressing the SV40 large T Antigen (TAg) under the control of the proximal promoter of the human MR (hMR, NR3C2) gene (P1-Tag) died prematurely from a malignant liposarcoma originating from BAT [14]. Moreover, T37i cells, derived from this hibernoma, are capable of undergoing terminal differentiation into brown adipocytes, which express UCP1 upon adrenergic or retinoic acid stimulation as well as endogenous functional MR [14]. We have previously shown that aldosterone, via MR activation, was able to induce differentiation of T37i cells into mature brown adipocytes [12]. Interestingly, aldosterone treatment induced a marked decrease in isoproterenol- and retinoic acid-stimulated UCP1 mRNA levels in a time- and dose-dependent manner [13]. MR interacts with coregulators (coactivators and corepressors) to modulate target gene transcription $[15,16]$. Some coregulators influence positively or negatively the transcription of nuclear receptor target genes, and are thus potential candidates involved in the balance between energy storage and expenditure [17]. Here, we aim at studying in vitro coregulator expression during T37i differentiation to identify MR transcriptional complexes by chromatin immunoprecipitation experiments. Our studies demonstrate in vivo the inhibitory effects of MR on UCP1 expression in the BAT and clarify the molecular mechanisms of MR inhibitory actions in T37i brown adipocytes.

\section{Materials and methods}

\subsection{Animals}

Two-week-old wild type (WT) and transgenic (Tg) male mice overexpressing hMR [18] were kept on a $12 \mathrm{~h}-12 \mathrm{~h}$ lightdark cycle in a temperature-controlled colony room. Mice were exposed to cold $\left(4^{\circ} \mathrm{C}\right)$ or to room temperature $\left(\mathrm{RT} ; 24^{\circ} \mathrm{C}\right)$ for $4 \mathrm{~h}$ and euthanized. Interscapular BAT was collected, weighted and proceeded for subsequent gene/protein expression studies. The animal facility was granted approval (No. C94-043-12), given by the "Ministère de l'Agriculture, de l'Agroalimentaire et de la Forêt". All mouse experimental procedures were approved by the local Ethics Committee CAPSUD No. 26, project No. 3106.

\subsection{Cell culture}

T37i cells were cultured as previously described [14]. Differentiation was achieved by incubating cells with $2 \mathrm{nM}$ triiodothyronine (Sigma-Aldrich, Saint Quentin Fallavier, France) and $20 \mathrm{nM}$ insulin (Sigma-Aldrich) for 4-8 days. For UCP1 expression studies, cells were incubated with medium supplemented with $10 \%$ dextran charcoal-coated serum and treated or not with $10 \mathrm{nM}$ aldosterone and with $1 \mu \mathrm{M}$ isoproterenol for $6 \mathrm{~h}$ or with $1 \mu \mathrm{M}$ RA or $1 \mu \mathrm{M}$ rosiglitazone overnight.

\subsection{Gene expression analysis}

Total RNA was extracted from BAT with QIAZOL (Qiagen, Courtaboeuf, France) and RNA Nucleospin Column (MachereyNagel, Hoerdt, France), and from T37i cells by TriReagent (Life Technologies, Villebon sur Yvette, France), respectively. Quantitative RT-PCR (RT-qPCR) was performed as described previously [19]. After DNAse I treatment and reverse transcription, samples were analyzed by RT-qPCR using the Power SYBR Green PCR Master Mix (Life Technologies) with the primers indicated (Supplementary Table S1) and a StepOne PCR System (Life Technologies). Relative expression in a given sample was calculated as a ratio (attomoles specific gene per femtomole $18 \mathrm{~S}$ or $36 \mathrm{~b} 4)$. Results are mean \pm SEM and normalized to the relative expression arbitrarily set at 1 for undifferentiated state or unstimulated condition. 


\subsection{Western Blot analysis}

Protein extracts were processed for multiplex detection of MR protein together with $\alpha$-tubulin for loading normalization; Blots on nitrocellulose membranes (LI-COR, Lincoln, NE, USA) were incubated for $1 \mathrm{~h}$ at room temperature (RT) in a blocking buffer ( $5 \%$ fat-free milk in Tris-buffer saline TBS with $0.1 \%$ Tween) before overnight incubation at $4{ }^{\circ} \mathrm{C}$ with a rabbit anti-MR $39 \mathrm{~N}$ antibody (1:1000 dilution) [19] and a mouse anti- $\alpha$-Tubulin antibody (1:5000 dilution, Sigma-Aldrich). After incubation for $1 \mathrm{~h}$ at RT with an IRDye 800-conjugated affinity purified anti-rabbit IgG second antibody (1:15,000 dilution, Life Technologies) and an IRDye 680-conjugated affinity purified anti-mouse IgG second antibody (1:15,000 dilution, Life Technologies), proteins were visualized with an Odyssey-Fc apparatus (LI-COR). Specific signals were normalized by $\alpha$ Tubulin signals as determined by densitometry using the Image Studio software (LI-COR).

\subsection{Chromatin Immunoprecipitation (ChIP) experiments}

ChIP were performed with HighCell\# ChIP kit (Diagenode, Seraing, Belgium) as described previously [16]. Samples of sheared chromatin were resuspended in $\mathrm{C} 1$ buffer in a total volume of $500 \mu \mathrm{l}$ containing anti-MR $39 \mathrm{~N}$ antibody $(7 \mu \mathrm{g})$ or anti-PPAR $\gamma$ antibody ( $2 \mu \mathrm{g}$ ) (Diagenode, C15410133), and $25 \mu \mathrm{l}$ of protein-A coated beads, and incubated overnight at $4{ }^{\circ} \mathrm{C}$ in a rotating shaker. Bead-antibody-chromatin complexes were eluted with $100 \mu$ l of DNA Isolation buffer containing $1 \%$ of proteinase $\mathrm{K}$ for $15 \mathrm{~min}$ at $55^{\circ} \mathrm{C}$ followed by inactivation at $100{ }^{\circ} \mathrm{C}$ for $15 \mathrm{~min}$. DNA containing supernatants and input samples ( $1 \%$ of sheared chromatin samples) were assayed for qPCR analysis. Primer sequences for genomic qPCR are presented in Supplementary Table S1.

\subsection{Statistical analysis}

Data are means \pm SEM. Mann-Whitney U test was used when appropriate to determine significant differences (GraphPad Software, San Diego, CA, USA). Values of $P<0.05$ were considered statistically significant.

\section{Results}

\subsection{Impact of cold exposure on UCP1 expression in BAT of MR overexpressing mice}

We have previously shown that aldosterone, via MR activation, was able to induce differentiation of T37i cells into mature brown adipocytes [12] and to inhibit UCP1 expression in vitro [13]. To examine whether MR overexpression was capable of affecting UCP1 expression in vivo, we used the transgenic mouse model (Tg) that overexpresses hMR under the control of its own proximal promoter [18]. We investigated whether hMR transgene was expressed in the BAT of Tg mice and analyzed the consequences on endogenous murine $\mathrm{MR}(\mathrm{Nr} 3 \mathrm{c} 2$, mMr) expression. As expected, hMR transcripts were only detected in BAT of
Tg mice but not of WT animals (Fig. 1A), without change in $\mathrm{mMr}$ transcript levels (Fig. 1B). We examined UCP1 expression in the BAT of these animals upon cold exposure, a condition known to increase UCP1 gene expression. Two-week-old WT and Tg mice were submitted to cold exposure $\left(4^{\circ} \mathrm{C}\right)$ or RT $\left(24^{\circ} \mathrm{C}\right)$ for $4 \mathrm{~h}$. As shown in Fig. 1C, UCP1 mRNA levels were slightly but significantly induced after cold exposure in WT mice, whereas this effect was blunted in Tg mice. This finding provides support for the anti-thermogenic effect of MR in vivo.

\subsection{Induction of adipogenic markers and corticosteroid receptors expression during $T 37$ i differentiation}

In order to further evaluate the molecular mechanisms involved in MR-dependent UCP1 repression, we used the T37i cell model that recapitulates brown adipocyte function [14]. During differentiation induced by insulin and triiodothyronine for 8 days, T37i cells progressively accumulated small lipid droplets, characteristic of mature brown adipocytes (Fig. 2A). This was accompanied by an increase in PPAR $\gamma$ and UCP1 expression (Fig. 2B), with a maximal expression in differentiated brown adipocytes (Day 8). Along with the induction of adipogenic markers, MR expression and its closely related receptor, the glucocorticoid receptor (GR) were also significantly induced at the differentiated state by approximately 15 - and 2.5-fold, respectively (Fig. 2B). Western Blot analysis showed that MR protein level increased by 2-3-fold at intermediate state (Fig. 2C) and by 5-fold in mature adipocytes (Fig. 2D), as compared to undifferentiated state.

\subsection{Expression profile of several MR coregulator $m R N A s$ during T37i differentiation}

Expression profile of coactivators and corepressors was also evaluated during T37i differentiation (Fig. 3). Interestingly, some MR coactivators (Fig. 3A-C) and corepressors (Fig. 3D-G) exhibited a distinct pattern of expression. Pgc-1 $\alpha$ expression progressively increased during T37i differentiation with a 400-fold induction (Fig. 3A). Src-1 expression also increased during $\mathrm{T} 37 \mathrm{i}$ maturation, yet its maximal expression occurred earlier than that of Pgc-1 $\alpha$, at the intermediate state (10-fold induction, Fig. 3B), and remained unchanged until the differentiated state. By contrast, Src-3 expression only displayed a transient 2-fold induction at intermediate state of differentiation (Fig. 3C). Likewise, MR corepressors (NcoR, Rip140, Pias1), displayed a very similar expression pattern (Fig. 3D-F). Their expression levels were transiently increased by 2-3-fold at intermediate state of differentiation then returned to basal levels in differentiated brown adipocytes. Pias 3 expression also followed a transient and moderate 1.3-fold induction $(P<0.01)$ at intermediate state (Fig. 3G), while its expression level at differentiated state was down-regulated by 2-fold as compared to the undifferentiated state. Such a transient and simultaneous peak of coregulator expression is consistent with a coordinated cooperation occurring during brown adipogenesis. 


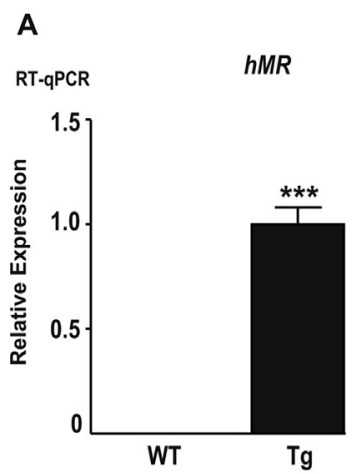

B

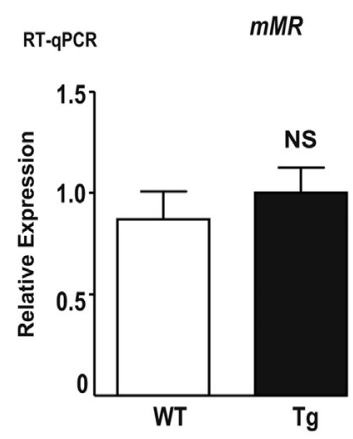

C

RT-qPCR UCP1

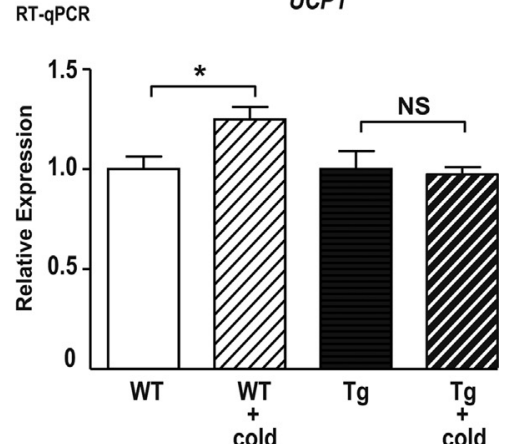

Fig. 1. Effect of cold exposure on UCP1 expression in vivo. Expression of human MR (hMR) in BAT (A) from WT mice $(n=6)$ and Tg mice $(n=6)$ and (B) murine MR (mMR) in BAT, analyzed by RT-qPCR. hMR expression was restricted to Tg mice without modification of endogenous MR (mMR) expression. Results are means \pm SEM and values measured in Tg mice were arbitrarily set to 1. (C) In 2-week-old WT mice, UCP1 expression was induced after a $4 \mathrm{~h}$ cold exposure as compared to animals maintained at room temperature. This adrenergic stimulation of BAT UCP1 expression was blunted in Tg animals. Results are expressed as mean $\pm \operatorname{SEM}\left(n=18\right.$ for WT RT, $n=15$ for WT cold, $n=19$ for Tg RT and $n=45$ for Tg cold). ${ }^{*} P<0.05$, RT vs cold exposure, NS: not significant.

\section{A}

+ Differentiation cocktail

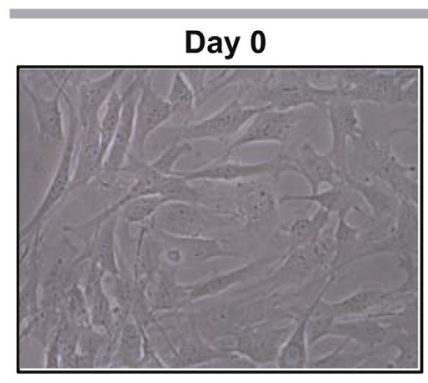

Undifferentiated state (U)

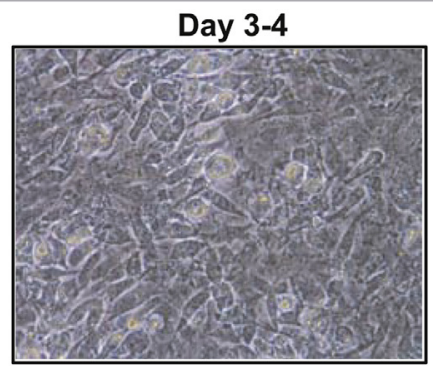

Intermediate state (I)
Day 8

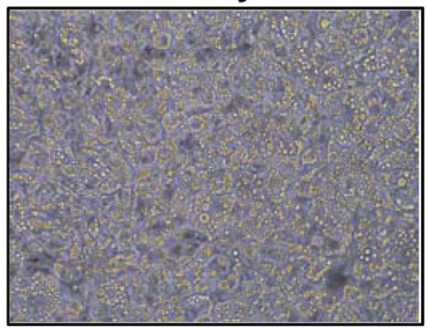

Differentiated state (D)

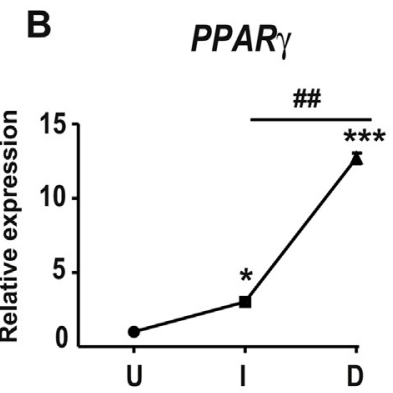

C

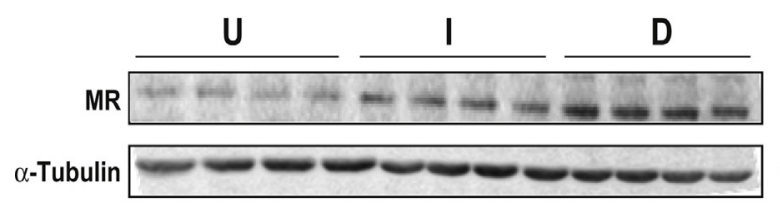

UCP1
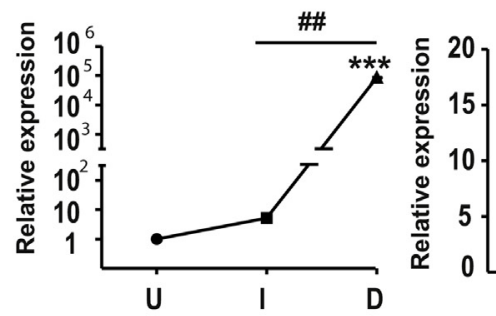

$M R$

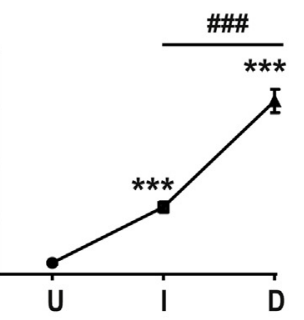

GR

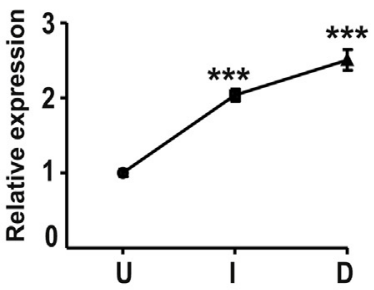

D

$130 \mathrm{kDa}$

$55 \mathrm{kDa}$

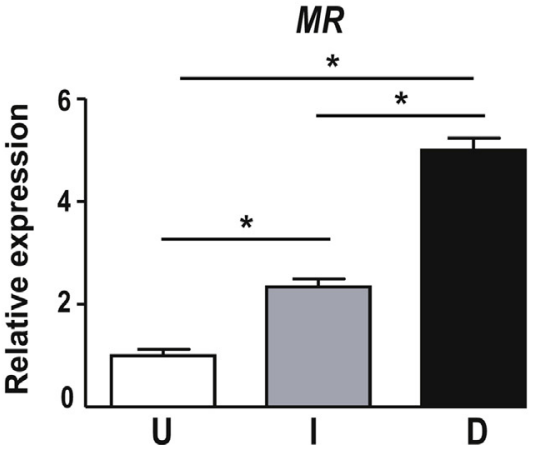

Fig. 2. Induction of adipogenic markers and corticosteroid receptors during adipogenesis. (A) During differentiation, T37i cells accumulate small lipid droplets. (B) Induction of adipogenic markers and corticosteroid receptors during T37i differentiation. (C and D) Western Blot analysis of MR expression during adipogenesis with quantification. Undifferentiated state $=\mathrm{U}, \mathrm{D} 0=$ day of differentiation induction; Intermediate state $=\mathrm{I}, \mathrm{D} 3-4=$ day $3-4$ after differentiation induction; Differentiated state $=\mathrm{D}, \mathrm{D} 8=$ day 8 after differentiation induction. Results are expressed as mean $\pm \operatorname{SEM}(n=6$ for PPAR $\gamma 2$ and UCP1, $n=12$ for MR and GR $){ }^{*} P<0.05 ;{ }^{* *} P<0.01$; ${ }^{* * * *} P<0.001$, I or D state vs. U state. ${ }^{\# \#} P<0.01,{ }^{\# \#} P<0.001$ I state vs. D state. 
A

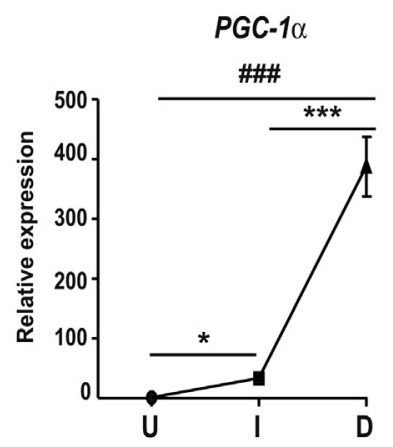

B

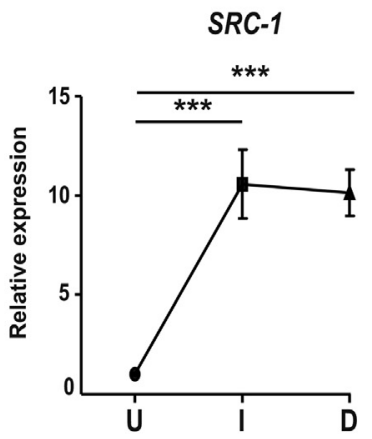

C

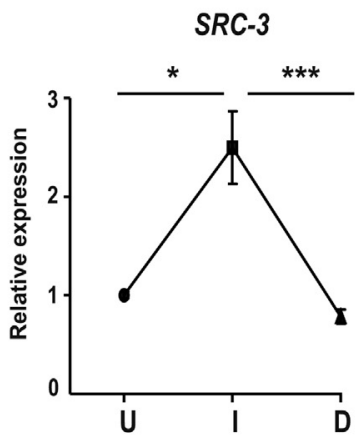

D

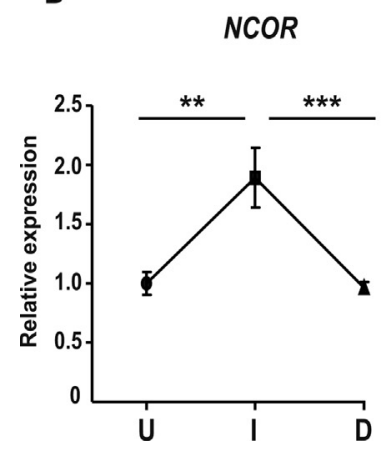

E

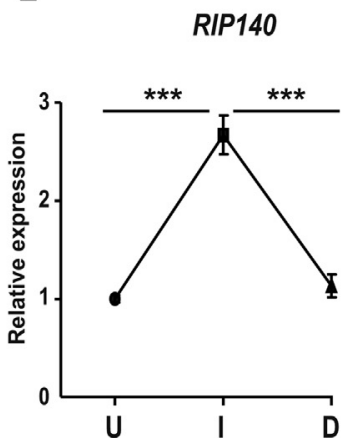

$\mathrm{F}$

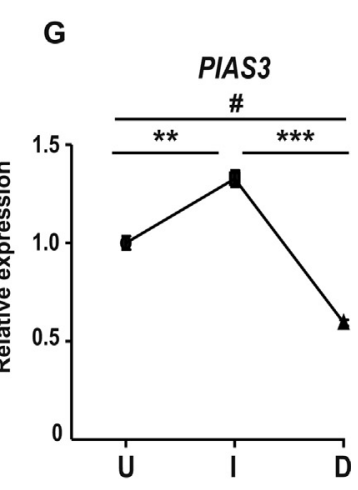

Fig. 3. Expression profile of MR coregulators during T37i differentiation. (A) Expression of PGC-1 $\alpha$ was drastically induced during T37i differentiation. (B) Expression of SRC-1 was induced at the intermediate state of differentiation and its expression level remained unchanged up to the differentiated state. (C) SRC-3 expression was transient with a peak at the intermediate state. (D) NcoR, (E) RIP140, (F) PIAS1 were transiently induced at intermediate state of differentiation, then returned to basal levels. (G) PIAS3 expression was transient during T37i differentiation with a peak at intermediate state, followed by a reduction lower than basal level. Undifferentiated state $=\mathrm{U}$, Intermediate state $=\mathrm{I}$, Differentiated state $=\mathrm{D}$. Results are expressed as mean $\pm \mathrm{SEM}(n=10$ for NcoR and PIAS1, $n=12$ for RIP140, $n=17$ for SRC-1, $n=18$ for SRC-3 and PIAS3). ${ }^{*} P<0.05 ;{ }^{* *} P<0.01 ;{ }^{* * * *} P<0.001$, I or D state vs U state. ${ }^{\#} P<0.05$; ${ }^{\# \# \#} P<0.001$ as compared to U state.

\subsection{Inhibitory effect of aldosterone on UCP1 expression in brown adipocytes}

We previously demonstrated that via MR activation, aldosterone acts as an anti-thermogenic factor by inhibiting UCP1 expression [13]. To confirm these findings, we used the more sensitive and quantitative technique of RT-qPCR. We examined the effect of aldosterone treatment on UCP1 expression induced by catecholamines (isoproterenol) or retinoic acid (RA) (Fig. 4), at different states of differentiation. As shown in Fig. 4A, UCP1 expression levels were very low in T37i cells at the intermediate state, irrespective of the presence of aldosterone. Upon isoproterenol stimulation, a 1000-fold increase in UCP1 expression was observed. Simultaneous treatment of T37i cells with isoproterenol and aldosterone for $6 \mathrm{~h}$ led to a $40 \%$ reduction in UCP1 expression. We performed the same experiment by incubating cells for $18 \mathrm{~h}$ with rosiglitazone $(1 \mu \mathrm{M})$, UCP1 expression is very low under basal conditions and after aldosterone exposure alone (Fig. 4B). Rosiglitazone stimulation induced a 20 -fold increase in UCP1 expression, which was partially but significantly prevented in the presence of aldosterone. Similar analysis was performed using RA treatment for $18 \mathrm{~h}$ (Fig. 4C). Under basal conditions, UCP1 was expressed at very low levels. RA induced a dramatic increase in UCP1 expression (100-fold as compared to basal conditions) that was reduced by $20 \%$ in the presence of aldosterone (Fig. 4C). At the differentiated state, basal level of UCP1 mRNA in differentiated T37i cells was higher than that of intermediate state. Treatment with RA increased UCP1 expression by 600 -fold, while co-incubation with aldosterone induced a similar significant $20 \%$ inhibition in UCP1 expression (Fig. 4D).

\subsection{MR recruitment on UCP1 regulatory sequences}

To identify the molecular mechanisms by which MR could repress UCP1 gene expression, we performed ChIP experiments using anti-PPAR $\gamma$ or anti-MR antibodies on T37i cells at intermediate state of differentiation after an overnight stimulation by RA with or without aldosterone. We examined a well-characterized enhancer region of the $5^{\prime}$-flanking region of the mouse UCP1 gene, which contains critical key regulatory cis-elements, including binding sequence for PPAR $\gamma$ (PPRE) as well as CRE half-sites and NF-E2 motifs, located $2.5 \mathrm{~kb}$ upstream of the transcription start site of UCP1 gene (Fig. 5A) [20]. Upon RA exposure, a 100-fold enrichment of PPAR $\gamma$ binding on UCP1 promoter was observed as compared to control condition (IgG), quantified by genomic qPCR (Fig. 5B). In the presence of aldosterone, PPAR $\gamma$ recruitment was further increased up to 370 -fold as compared to $\mathrm{IgG}$ condition and by 4fold compared with RA exposure alone. These results indicated that PPAR $\gamma$ was recruited on PPRE-containing sequences of UCP1 promoter in T37i cells and suggested that MR activation 
A
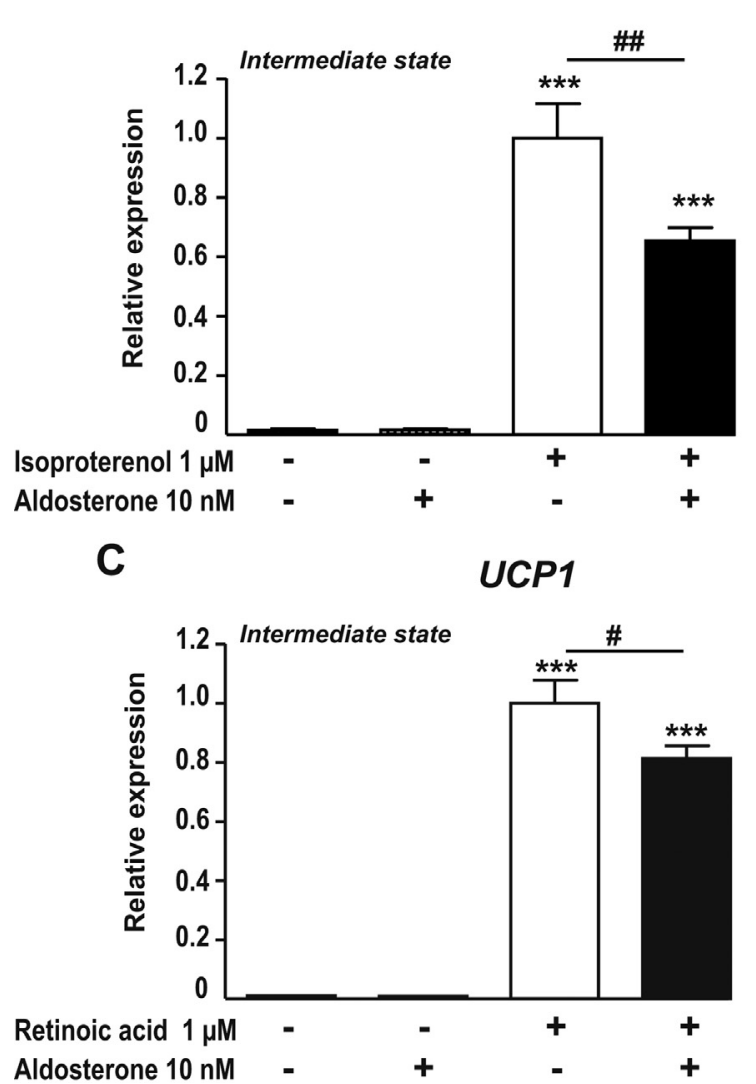

B
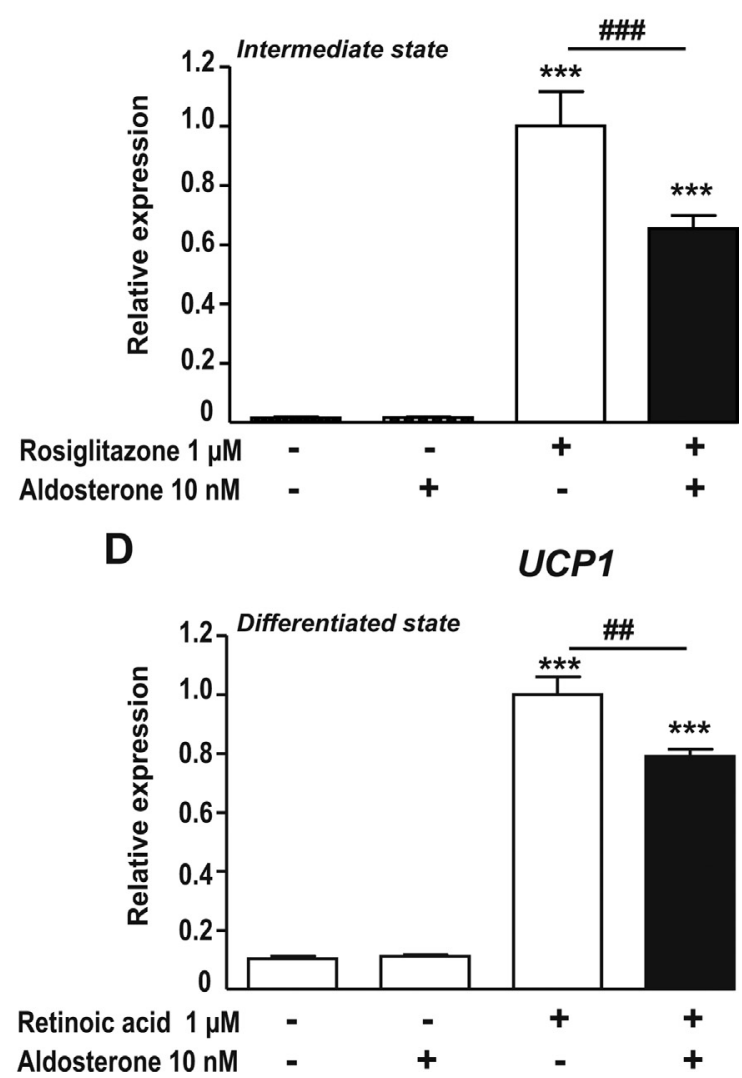

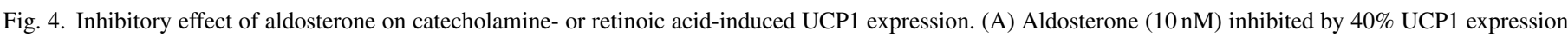

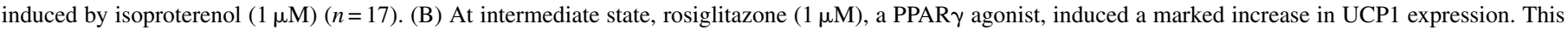

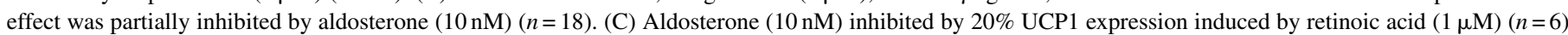

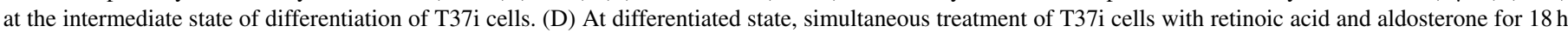

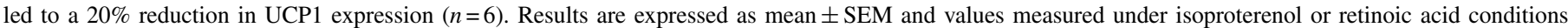

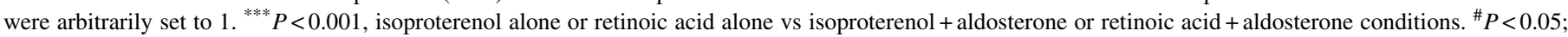

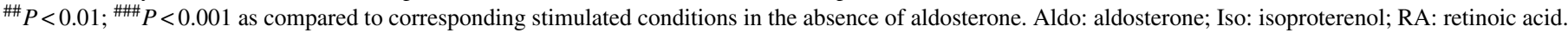

by aldosterone stimulates this recruitment. We performed similar experiments using an anti-MR antibody (39 N). In presence of RA, MR was already bound to UCP1 regulatory sequence with a 39-fold enrichment compared to control condition (Fig. 5B). This recruitment was enhanced upon aldosterone treatment by a 136-fold factor as compared to basal conditions. These results support the hypothesis that after RA stimulation, MR, possibly via interaction with PPAR $\gamma$-RXR hetero-complexes, binds directly or indirectly to UCP1 regulatory sequences. Importantly, this recruitment is further enhanced after aldosterone exposure, associated with concomitant transrepression of UCP1 expression (see also Fig. 4 for comparison).

\section{Discussion}

In the kidney, MR plays a key role in hydroelectrolytic homeostasis [21]. However, MR is also expressed in non-epithelial tissues such adipose tissues where it promotes adipogenesis $[12,22-24]$. We previously demonstrated that aldosterone through MR activation exerts an anti-thermogenic activity [13] in vitro by using the T37i cell line [14]. Therefore, we wanted to investigate the MR inhibitory effect on UCP1 expression in vivo, by using previously characterized MR-overexpressing mice ( $\mathrm{Tg})$ [18]. Cold exposure during $4 \mathrm{~h}$, a condition known to stimulate catecholamine release, modestly but significantly increased UCP1 expression in BAT of 2-week-old WT mice, whereas this induction was blunted in $\mathrm{Tg}$ mice, in accordance with in vitro studies and providing support for an anti-thermogenic role of MR in vivo. In vitro, T37i cells represent a suitable cell-based system to characterize in vitro MR coregulators involved in proadipogenic and anti-thermogenic effects of MR because these cells express endogenous $\mathrm{mMR}$ and recapitulate after differentiation the functions of brown adipocytes [12]. Here, we show that expression profile of coregulators is variable during brown adipogenesis. We confirm that aldosterone inhibits catecholamineor PPAR $\gamma$ agonist-stimulated UCP1 expression and demonstrate by ChIP that MR and PPAR $\gamma$ interact with UCP1 promoter sequences.

T37i cells undergo full adipocyte maturation accompanied by morphological changes and induction of Ppary and UCP1, in accordance with previous studies [12]. We show that GR expression is induced by 2 -fold whereas MR expression is 


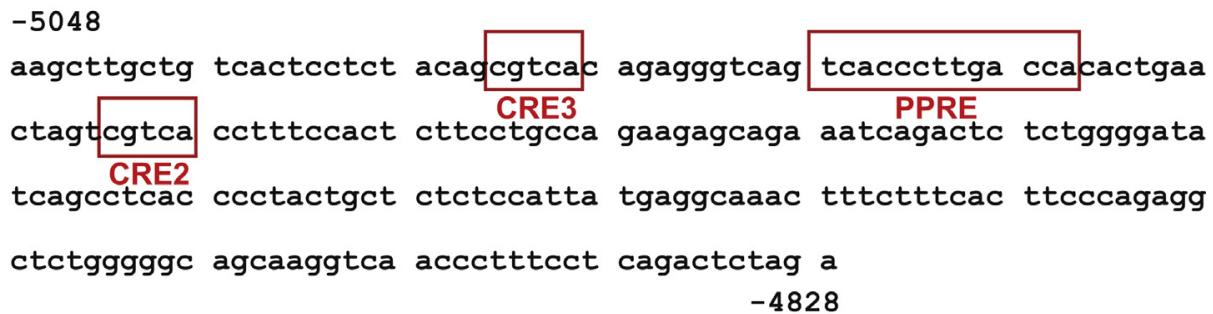

B

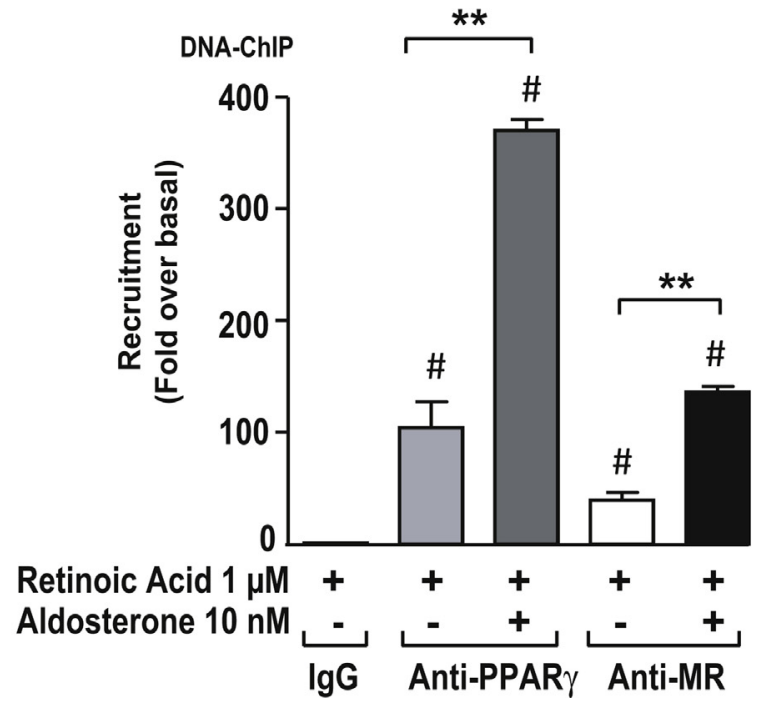

Fig. 5. MR recruitment on UCP1 promoter. (A) Nucleotide sequence and schematic representation of BAT-specific region of the UCP1 gene [20]. (B) In presence of RA $(1 \mu \mathrm{M})$, PPAR $\gamma$ and MR were recruited onto the UCP1 promoter sequence as determined by ChiP experiments. Recruitment of PPAR $\gamma$ and MR on UCP1 promoter sequence significantly increased upon aldosterone exposure. Results are means \pm SEM of 2 independent experiments performed in triplicate and values measured in IgG condition were arbitrarily set to $1 .{ }^{\#} P<0.05$, (vs. IgG condition), ${ }^{* *} P<0.01$ (RA+ aldosterone vs. RA alone).

drastically induced (15-fold at the mRNA level and 5-fold at the protein level) during brown adipogenesis. Likewise, this was also observed in 3T3-L1 white adipocytes with a lower GR induction [22].

We characterize MR coregulator expression during brown adipocyte differentiation. This is the first study analyzing such a MR coregulator expression in brown adipocytes, although this was already reported in white adipocytes [25]. During adipocyte maturation, expression of Pgc-1 $1 \alpha$, a key coregulator of BAT development [26], increases as early as 3 days of differentiation. At the intermediate state, its expression is induced by 30 -fold compared to basal level and by 400 -fold at the differentiated state. Induction of Pgc-1 $\alpha$ expression seems to occur before UCP1 surge, in accordance with its role in brown adipogenesis [25]. While Src-1 expression drastically increases at the intermediate state and is maintained at the differentiated state, Src-3 is transiently induced by 2.5 -fold at intermediate state. This result may reflect a different involvement of these two p160 coregulators in brown adipogenesis, as depicted in white adipogenesis. Indeed, in mouse embryonic fibroblasts derived from Src-3 null $\left(\right.$ Src- $\left.3^{-1-}\right)$ animals exhibited an altered white adipocyte differentiation, whereas Src-1 knockdown did not change their differentiation [27].
In sharp contrast, corepressors have a transient and cyclic expression with a 1.5- to 3-fold induction at the intermediate state compared to basal state, while their expression level in mature adipocytes returns to basal level, except for Pias3. Of particular interest, peak expression at intermediate state coincides with a critical step during adipogenesis i.e the onset of lipid droplet accumulation. Thus, corepressor expression is at the highest level prior to lipid droplet formation and then decreases progressively along with adipocyte maturation. This is consistent with previous studies demonstrating that $\mathrm{NcoR}$ or RIP140 could inhibit adipogenesis [28,29] and UCP1 promoter activity [30]. Finally, such a transient and simultaneous peak of coregulator expression is consistent with a functional balance occurring during brown adipogenesis. Further studies are required to determine which coregulators are essential for brown adipocyte differentiation.

We next examine the main function of brown adipocytes in the BAT i.e., thermogenesis, and its regulatory mechanisms, notably by aldosterone-activated MR. We show that aldosterone treatment leads to a 20 to $40 \%$ reduction in UCP1 mRNA expression induced by isoproterenol, rosiglitazone or RA. We previously demonstrated that aldosterone inhibits UCP1 transcription through a MR-mediated mechanism [13]. 
A
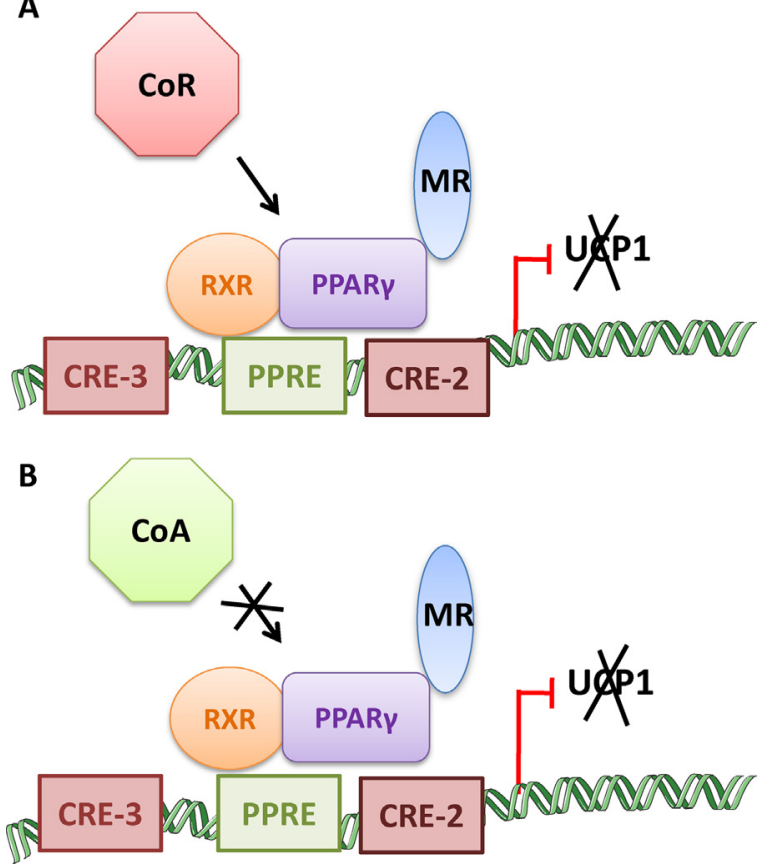

Fig. 6. Schematic representation of MR recruitment on UCP1 promoter. (A) Recruitment of a corepressor of preinitiation transcriptional complex including MR and PPAR on regulatory sequences of the murine ucp1 promoter region. (B) Alternatively or concomitantly, the recruitment of a unknown coactivator might be prevented on such a transcriptional complex, leading in both cases to a transrepression of ucp1 transcription.

MR-mediated inhibition of UCP1 expression by aldosterone could be due to some kind of squelching mechanism of PPAR $\gamma$ partner through a functional interaction between MR and PPAR $\gamma$. We used ChIP to determine if MR could physically interact with some regulatory sequences of UCP1 gene. PPAR $\gamma$ recruitment is significantly enhanced on UCP1 promoter motif following RA exposure but, importantly, it is further enhanced in the presence of aldosterone. These results clearly indicate that PPAR $y$ binds to PPRE-containing sequences of UCP1 promoter in T37i cells and suggest that MR activation by aldosterone modulates this recruitment. MR also binds to the same genomic target sequence of UCP1 promoter while aldosterone enhances MR recruitment. Collectively, our findings suggest that aldosterone-activated MR promotes binding of transcriptional complexes onto a BAT-specific UCP1 enhancer, thus modifying the functional properties of the active preinitiation complexes and altering UCP1 gene expression. It could be hypothesized that coregulator recruitment is affected either through enhanced interaction with corepressors or via reduction of the recruitment of specific coactivators, or both, modifying the dynamics and the composition of functional transcriptional preinitiation complexes, as depicted in Fig. 6A and B. Indeed, it was described that RIP140 could directly inhibit UCP1 promoter activity [30] and could interact with another nuclear receptor such as LXR (Liver X Receptor) to repress UCP1 expression [31]. Several lines of evidence suggest that PPAR $\gamma$ recruits the transcriptional corepressors NCoR and SMRT to downregulate PPAR $\gamma$-mediated transcriptional activity [29].
Taken together, we provide evidence that MR, both in vivo and in vitro, is involved in the transrepression of UCP1 in brown adipocytes. Thus, it is very likely that in vivo, adipose tissue MR mediates glucocorticoid effects [22]. Indeed, GR has a relative minor contribution in adipose tissue growth [24], this suggests that MR could largely contribute to the anti-thermogenic activity of glucocorticoids [28].

Altogether, our results demonstrate for the first time a transient and simultaneous peak of coregulator expression during brown adipogenesis and show that UCP1 expression is inhibited by MR in vitro and in vivo. Our findings indicate that MR exerts a metabolic role by inhibiting UCP1 expression and provide novel information on how MR regulates brown adipocyte function. Further studies are required to determine the nature of coregulators responsible for brown adipocyte development and their precise involvement in the anti-thermogenic effect of corticosteroids. We also demonstrate a new interaction of MR and PPAR $\gamma$ on DNA regulatory sequences, emphasizing a novel mechanism of MR signaling that may potentially occur on other genes as well as in different cellular contexts.

\section{Fundings}

This work was supported by a CORDDIM fellowship (Cardiovasculaire-Obésité-Rein-Diabète-Domaine d'Intérêt Majeur; Région Île-de-France) to E. Kuhn, and funding grants from Institut National de la Santé et de la Recherche Médicale, Université Paris-Sud, Université Pierre-et-MarieCurie (UMPC) and Agence Nationale de la Recherche ANR (EPHIMIR ANR 11BSV1 028 01).

\section{Disclosure of interest}

The authors declare that they have no competing interest.

\section{Appendix A. Supplementary data}

Supplementary data associated with this article can be found, in the online version, at https://doi.org/10.1016/j.ando.2018.04. 018.

\section{References}

[1] Nedergaard J, Cannon B. The browning of white adipose tissue: some burning issues. Cell Metab 2014;20:396-407, http://dx.doi.org/ 10.1016/j.cmet.2014.07.005.

[2] Schrauwen P, van Marken Lichtenbelt WD. Combatting type 2 diabetes by turning up the heat. Diabetologia 2016;59:2269-79, http://dx.doi.org/10.1007/s00125-016-4068-3.

[3] Ricquier D. Respiration uncoupling and metabolism in the control of energy expenditure. Proc Nutr Soc 2005;64:47-52.

[4] Barbera MJ, Schluter A, Pedraza N, Iglesias R, Villarroya F, Giralt M. Peroxisome proliferator-activated receptor alpha activates transcription of the brown fat uncoupling protein-1 gene. A link between regulation of the thermogenic and lipid oxidation pathways in the brown fat cell. J Biol Chem 2001;276:1486-93, http://dx.doi.org/10.1074/jbc.M006246200.

[5] Cederberg A, Grønning LM, Ahrén B, Taskén K, Carlsson P, Enerbäck $\mathrm{S} . \mathrm{FOXC2}$ is a winged helix gene that counteracts obesity, hypertriglyceridemia, and diet-induced insulin resistance. Cell 2001;106:563-73. 
[6] Feldmann HM, Golozoubova V, Cannon B, Nedergaard J. UCP1 ablation induces obesity and abolishes diet-induced thermogenesis in mice exempt from thermal stress by living at thermoneutrality. Cell Metab 2009;9:203-9, http://dx.doi.org/10.1016/j.cmet.2008.12.014.

[7] Gadea E, Thivat E, Paulon R, Mishellany F, Gimbergues P, Capel F, et al. Hibernoma: a clinical model for exploring the role of brown adipose tissue in the regulation of body weight? J Clin Endocrinol Metab 2014;99:1-6, http://dx.doi.org/10.1210/jc.2013-2829.

[8] Kopecky J, Clarke G, Enerbäck S, Spiegelman B, Kozak LP. Expression of the mitochondrial uncoupling protein gene from the aP2 gene promoter prevents genetic obesity. J Clin Invest 1995;96:2914-23, http://dx.doi.org/10.1172/JCI118363.

[9] Lowell BB, S-Susulic V, Hamann A, Lawitts JA, Himms-Hagen J, Boyer BB, et al. Development of obesity in transgenic mice after genetic ablation of brown adipose tissue. Nature 1993;366:740-2, http://dx.doi.org/10.1038/366740a0.

[10] Boon MR, Kooijman S, van Dam AD, Pelgrom LR, Berbée JFP, Visseren CAR, et al. Peripheral cannabinoid 1 receptor blockade activates brown adipose tissue and diminishes dyslipidemia and obesity. FASEB J 2014;28:5361-75, http://dx.doi.org/10.1096/fj.13-247643.

[11] van Dam AD, Nahon KJ, Kooijman S, van den Berg SM, Kanhai AA, Kikuchi T, et al. Salsalate activates brown adipose tissue in mice. Diabetes 2015;64:1544-54, http://dx.doi.org/10.2337/db14-1125.

[12] Penfornis P, Viengchareun S, Le Menuet D, Cluzeaud F, Zennaro MC, Lombès M. The mineralocorticoid receptor mediates aldosteroneinduced differentiation of T37i cells into brown adipocytes. Am J Physiol Endocrinol Metab 2000;279:E386-94.

[13] Viengchareun S, Penfornis P, Zennaro MC, Lombès M. Mineralocorticoid and glucocorticoid receptors inhibit UCP expression and function in brown adipocytes. Am J Physiol Endocrinol Metab 2001;280:E640-9.

[14] Zennaro MC, Le Menuet D, Viengchareun S, Walker F, Ricquier D, Lombès M. Hibernoma development in transgenic mice identifies brown adipose tissue as a novel target of aldosterone action. J Clin Invest 1998;101:1254-60, http://dx.doi.org/10.1172/JCI1915.

[15] Yang J, Fuller PJ. Interactions of the mineralocorticoid receptor - within and without. Mol Cell Endocrinol 2012;350:196-205, http://dx.doi.org/10.1016/j.mce.2011.07.001.

[16] Le Billan F, Khan JA, Lamribet K, Viengchareun S, Bouligand J, Fagart J, et al. Cistrome of the aldosterone-activated mineralocorticoid receptor in human renal cells. FASEB J 2015;29:3977-89, http://dx.doi.org/10.1096/fj.15-274266.

[17] Mouchiroud L, Eichner LJ, Shaw RJ, Auwerx J. Transcriptional coregulators: fine-tuning metabolism. Cell Metab 2014;20:26-40, http://dx.doi.org/10.1016/j.cmet.2014.03.027.

[18] Le Menuet D, Isnard R, Bichara M, Viengchareun S, Muffat-Joly M, Walker F, et al. Alteration of cardiac and renal functions in transgenic mice overexpressing human mineralocorticoid receptor. J Biol Chem 2001;276:38911-20, http://dx.doi.org/10.1074/jbc.M103984200.
[19] Viengchareun S, Kamenicky P, Teixeira M, Butlen D, Meduri G, Blanchard-Gutton $\mathrm{N}$, et al. Osmotic stress regulates mineralocorticoid receptor expression in a novel aldosterone-sensitive cortical collecting duct cell line. Mol Endocrinol Baltim Md 2009;23:1948-62, http://dx.doi.org/10.1210/me.2009-0095.

[20] Rim JS, Kozak LP. Regulatory motifs for CREB-binding protein and $\mathrm{Nfe} 212$ transcription factors in the upstream enhancer of the mitochondrial uncoupling protein 1 gene. J Biol Chem 2002;277:34589-600, http://dx.doi.org/10.1074/jbc.M108866200.

[21] Viengchareun S, Le Menuet D, Martinerie L, Munier M, Pascual-Le Tallec $\mathrm{L}$, Lombès $\mathrm{M}$. The mineralocorticoid receptor: insights into its molecular and (patho)physiological biology. Nucl Recept Signal 2007;5:e012, http://dx.doi.org/10.1621/nrs.05012.

[22] Caprio M, Fève B, Claës A, Viengchareun S, Lombès $M$, Zennaro MC. Pivotal role of the mineralocorticoid receptor in corticosteroid-induced adipogenesis. FASEB J 2007;21:2185-94, http://dx.doi.org/10.1096/fj.06-7970com.

[23] Rondinone CM, Rodbard D, Baker ME. Aldosterone stimulated differentiation of mouse 3T3-L1 cells into adipocytes. Endocrinology 1993;132:2421-6.

[24] Desarzens S, Faresse N. Adipocyte glucocorticoid receptor has a minor contribution in adipose tissue growth. J Endocrinol 2016;230:1-11, http://dx.doi.org/10.1530/JOE-16-0121.

[25] Fu M, Sun T, Bookout AL, Downes M, Yu RT, Evans RM, et al. A Nuclear Receptor Atlas: 3T3-L1 adipogenesis. Mol Endocrinol Baltim Md 2005;19:2437-50, http://dx.doi.org/10.1210/me.2004-0539.

[26] Puigserver P, Wu Z, Park CW, Graves R, Wright M, Spiegelman BM. A cold-inducible coactivator of nuclear receptors linked to adaptive thermogenesis. Cell 1998;92:829-39.

[27] Louet J-F, Coste A, Amazit L, Tannour-Louet M, Wu R-C, Tsai SY, et al. Oncogenic steroid receptor coactivator-3 is a key regulator of the white adipogenic program. Proc Natl Acad Sci U S A 2006;103:17868-73, http://dx.doi.org/10.1073/pnas.0608711103.

[28] Hampl R, Stárka L, Janský L. Steroids and thermogenesis. Physiol Res Acad Sci Bohemoslov 2006;55:123-31.

[29] Yu C, Markan K, Temple KA, Deplewski D, Brady MJ, Cohen RN. The nuclear receptor corepressors NCoR and SMRT decrease peroxisome proliferator-activated receptor gamma transcriptional activity and repress 3T3-L1 adipogenesis. J Biol Chem 2005;280:13600-5, http://dx.doi.org/10.1074/jbc.M409468200.

[30] Fritah A, Christian M, Parker MG. The metabolic coregulator RIP140: an update. Am J Physiol Endocrinol Metab 2010;299:E335-40, http://dx.doi.org/10.1152/ajpendo.00243.2010.

[31] Wang H, Zhang Y, Yehuda-Shnaidman E, Medvedev AV, Kumar N, Daniel KW, et al. Liver receptor alpha is a transcriptional repressor of the uncoupling protein 1 gene the brown fat phenotype. Mol Cell Biol 2008;28:2187-200, http://dx.doi.org/10.1128/MCB.01479-07. 